\title{
Trisomy 21 mosaicism in two successive generations in a family*
}

\author{
JAMES C PARKE JR, FRANK S GRASS, ROLAND PIXLEY, AND \\ JANE DEAL \\ From the Clinical Genetics Program, Departments of Pediatrics and Obstetrics-Gynecology, \\ Charlotte Memorial Hospital and Medical Center, PO Box 32861, Charlotte, North Carolina 28232, USA
}

SUMMARY The occurrence of $46, \mathrm{XX} / 47, \mathrm{XX},+21$ mosaicism in two successive generations implies. $\vec{\nabla}$ an aetiological relationship between the $47, X X,+21$ cell line of the mother and her daughter.

\section{Case report}

The proband is a 20 -year-old white female with the typical clinical features of Down's syndrome including upward slanting palpebral fissures, rounded and flat facies, Brushfield spots, epicanthal folds, short stature, and mental retardation. She was evaluated at the age of 20 years by a clinical psychologist who reported her IQ to be 46 . No chromosome studies had been performed.

The mother was 24 years of age at the time of the proband's birth, and it was her fourth pregnancy. The first three pregnancies ended in spontaneous abortion by the fourth month of gestation. The fifth and sixth pregnancies were carried to term with delivery of normal females.

\section{CYTOGENETIC STUDIES}

A chromosome analysis performed by routine Giemsa staining on the peripheral blood of the affected daughter showed a mosaic form of Down's syndrome (table). Of 100 cells examined, $54 \%$ were $46, \mathrm{XX}$ and $41 \%$ were $47, \mathrm{XX},+21$. A total of $5 \%$ of the cells had 45 chromosomes with random loss of different chromosomes.

TABLE Results of chromosome analyses on various tissues of mother and 3 daughters

\begin{tabular}{llclcc}
\hline Patient & Tissue & $\begin{array}{l}\text { Cells } \\
\text { counted }\end{array}$ & $46, X X$ & $\begin{array}{l}47, X X,+ \\
21\end{array}$ & $\begin{array}{l}\% \text { trisomic } \\
21\end{array}$ \\
\hline Mother & Blood & 101 & 99 & 2 & $1 \cdot 98$ \\
& Skin & 92 & 92 & 0 & 0 \\
Daughter 1 & Ovary & 35 & 33 & 2 & $5 \cdot 71$ \\
Baughter 2 & Blood & 100 & 54 & 41 & $41 \cdot 00$ \\
Daughter 3 & Blood & 50 & 50 & 0 & 0 \\
& Skin & 30 & 50 & 0 & 0 \\
& Skin & 30 & 30 & 0 & 0 \\
\hline
\end{tabular}

*Supported in part by Medical Service Grant C-103, National Foundation-March of Dimes.

Received for publication 8 May 1979
Discovery of mosaicism in the proband prompted $\rightarrow$ chromosome analyses of her sisters, neither of whom ${ }_{\mathbb{D}}^{\top}$ displayed features of Down's syndrome. Peripheralo

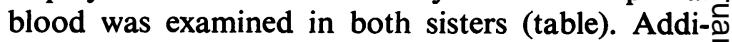
tionally, chromosomes were examined from cultured ${ }^{2}$ fibroblasts from one of the sisters. A normal 46,XX $\overrightarrow{0}$ chromosome constitution was observed in each ${ }^{\infty}$ sample.

The mother of the proband showed no features of Down's syndrome, but her poor reproductive history indicated that a chromosome analysis would beo appropriate (table). Of the 101 leucocytes examined, $\frac{\mathrm{D}}{\mathrm{Q}}$ $2 \%$ were $47, X X,+21$. These trisomic cells were the 36th and 54th examined. Finally, cells cultured fromo an ovarian biopsy performed when the mother under- 3 went abdominal surgery showed a $47, \mathrm{XX},+21$ 贾 chromosome constitution in $6 \%$ of the cells examined.

The proband's father refused a chromosome analysis.

\section{Discussion}

There have been numerous examples of a parent who윽 was phenotypically normal or who displayed only? minor features of Down's syndrome, and who was found to have a low percentage of $47, \mathrm{XX}$ or $\mathrm{XY},+21 \mathrm{~N}$ cells, producing offspring with standard trisomy $21_{N}$ Down's syndrome. ${ }^{1-5}$ We are not aware of a previous report of a mosaic child born to a mosaic parent.

Two questions arise from this study. (1) Do the two cell lines observed in the mother's peripheral bloode cultures and her ovarian tissue represent true mosaicism or random gain and loss? (2) Did the $47, X X,+21$ cell line of the mother contribute to the trisomic 21 cell line of the daughter?

In relation to the first question, the practice of? some investigators has been to consider very low 
percentage mosaicism to be an artefact. Bochkov et $a l^{6}$ do not consider subjects in whom a minority cell line represents less than $25 \%$ of the total cell population to be true mosaics. Penrose ${ }^{7}$ excluded from the category of mosaics those persons whose minority cell line forms a proportion of less than $10 \%$ of the total. Such percentage limits do not take into account the type of tissue sampled.

Although only $2 \%$ and $6 \%$ of the cells in the peripheral blood and ovarian tissue of the mother in the present case showed the minority cell line, in all such metaphases chromosome 21 was present in triplicate. The quality of the preparations was such that excessive bursting and spreading of the cells did not occur, and in no cells were fewer than 46 chromosomes observed. These observations argue against random gain and loss.

The production of standard trisomy 21 Down's syndrome children by a parent with a low percentage of trisomy 21 cells is not without precedent. Richards ${ }^{4}$ reviewed 17 cases of mosaic parents with affected children. Twelve of these mosaic parents showed $10 \%$ or fewer $47, \mathrm{XX},+21$ cells in blood or skin or both, and in five of these the trisomic cell line constituted only 2 to $3 \%$ of the cell population. Nuzzo et $a l^{8}$ reported a case in which the mother of an affected child had only $0.87 \%$ mosaicism for trisomy 21 in skin fibroblasts.

In relation to the second question, this case implicates the $47, \mathrm{XX},+21$ cell line of the mosaic mother in contributing to the trisomic 21 cell line of the mosaic daughter. That $6 \%$ of the ovarian cells grown in tissue culture were $47, \mathrm{XX},+21$ supports his hypothesis. The ovarian cells examined were fibroblastic and may not accurately reflect the percentage mosaicism present in the oogonial cell line, which may be greater. Recent data concerning the high frequency of prenatal loss in Down's syndrome ${ }^{9}$ would suggest that the mother's three spontaneous abortions could have been trisomic 21 fetuses. However, the three fetuses were not studied.

A child mosaic for Down's syndrome can develop either from a normal zygote or a trisomy 21 zygote in which mitotic non-disjunction occurs during cleavage. Richards, ${ }^{4}$ calculating the proportions of mosaics derived from normal and trisomic zygotes, determined that $52.7 \%$ of mosaic parents are derived from normal zygotes, whereas only $19.1 \%$ of mosaic children with clinical Down's syndrome are derived from normal zygotes. Thus, the mother in the present case probably originated as a normal zygote. A mitotic non-disjunctional event occurred which produced a trisomic 21 cell line that proliferated into several tissues including reproductive tissue. The mosaic daughter was derived by secondary non-disjunction from a 47,XX, +21 oogonial cell. A mitotic non-disjunctional event occurred which produced a normal diploid cell line. The absence of appropriate cytological markers and the inability to perform a chromosome analysis on the father prevented a more precise determination of the origin of the daughter's mosaicism.

Although the routine examination of large numbers of cells from different tissues of all parents with Down's syndrome children would be impractical, ${ }^{10}$ such procedures would seem to be warranted in familial Down's syndrome or in couples who have had multiple spontaneous abortions and have produced an affected child, even when that child displays a mosaic form of Down's syndrome.

The family presented here suggests that a tendency towards mitotic non-disjunction may be present in some families. This tendency is manifested in mosaic subjects in successive generations and may reflect abnormalities in the genetic control of mitosis. Support of this hypothesis by additional reports of investigations involving large numbers of cells from different tissues in parents of mosaics would have a profound influence on the estimation of recurrence risks of mosaic Down's syndrome.

\section{References}

1 Kaffe S, Hsu LYF, Hirschhorn K. Trisomy 21 mosaicism in a woman with two children with trisomy 21 Down's syndrome. J Med Genet $1974 ; 11: 378-9$.

2 Mark HFL, Mendoza T, Abuelo D, Beauregard LJ, May JB, LaMarche PH. Reproduction in a woman with low percentage t(21q21q) mosaicism. J Med Genet 1977; 14:221-3.

3 Priest JH, Brantley KE, Blackstone MN, Blackstone RD. Parental mosaicism as a cause of Down syndrome. $J$ Pediatr 1977;90:786-8.

4 Richards BW. Investigation of 142 mosaic mongols and mosaic parents of mongols; cytogenetic analysis and maternal age at birth. J Ment Defic Res 1974;18:199-208.

5 Smith DW, Therman EM, Patau KA, Inhorn SL. Mosaicism in mother of two mongoloids. Am J Dis Child 1962;104:534.

6 Bochkov NP, Kaleshov NP, Chebotarev AN, Alekhin VI, Midian SA. Population cytogenetic investigation of newborns in Moscow. Humangenetik 1974;22:139-52.

7 Penrose LS. Studies on mosaicism in Down's anomaly. In: Jarvis GA, ed. Mental retardation. Springfield: CC Thomas, 1967.

8 Nuzzo F, Stefanini M, Simoni G, Larizza L, Mottura A, Reali E, Franceschini P. A family with three sibs carrying trisomy 21. Ann Genet 1975;18:111-6.

9 Hook EB. Spontaneous deaths of fetuses with chromosomal abnormalities diagnosed prenatally. $N$ Engl J Med $1978 ; 299: 1036-8$.

10 Mehes K. Detection of parental mosaicism in Down syndrome. J Pediatr 1978;92:692.

Requests for reprints to Dr J C Parke Jr, Department of Pediatrics, Charlotte Memorial Hospital and Medical Center, PO Box 32861, Charlotte, North Carolina 28232, USA. 